\title{
Faktor-Faktor yang Mempengaruhi Tingkat Pengangguran di Kabupaten Jember
}

\author{
Factors Affecting of Unemployment Rate in Jember Regency
}

\author{
Riza Firdhania, Fivien Muslihatinningsih ${ }^{1}$ \\ Jurusan Ilmu Ekonomi, Fakultas Ekonomi, Universitas Jember (UNEJ) \\ Jln. Kalimantan 37, Jember 68121 \\ E-mail: fmn.feunej@gmail.com
}

\begin{abstract}
Abstrak
Penelitian ini bertujuan menjelaskan hubungan antara jumlah penduduk, inflasi, upah minimum, pertumbuhan ekonomi, dan indeks pembangunan manusia terhadap tingkat pengangguran di Kabupaten Jember. Jenis data yang digunakan dalam penelitan ini adalah data sekunder yang berupa data time series yang diperoleh dari Disnaker Kabupaten Jember dan Badan Pusat Statistik Kabupaten Jember tahun 2002-2013. Metode analisis data yang digunakan dalam penelitian ini adalah analisis deskriptif statistik dan analisis regresi linear berganda. Uji hipotesis menggunakan pengujian parsial (uji t), simultan (uji F), dan koefisien determinasi $\left(\mathrm{R}^{2}\right)$. Uji asumsi klasik menggunakan uji normalitas, multikolinearitas, heteroskedastisitas, dan autokorelasi. Dari hasil analisis data menunjukkan bahwa jumlah penduduk berpengaruh positif dan signifikan terhadap tingkat pengangguran di Kabupaten Jember. Varibel inflasi, upah minimum, dan indeks pembangunan manusia berpengaruh negatif dan signifikan terhadap tingkat pengangguran di Kabupaten Jember. Sedangkan variabel pertumbuhan ekonomi berpengaruh positif dan tidak signifikan terhadap tingkat pengangguran di Kabupaten Jember. Secara simultan hasil analaisis data menunjukkan jumlah penduduk, inflasi, upah minimum, pertumbuhan ekonomi dan indeks pembangunan manusia berpengaruh signifikan terhadap tingkat pengangguran di Kabupaten Jember.
\end{abstract}

Kata Kunci: Inflasi, Indeks Pembangunan Manusia, Jumlah Penduduk, Pertumbuhan Ekonomi, Upah Minimum.

\section{Abstract}

This research describes the relation between variables of population, inflation, minimum wage, economic growth, and human development index toward the unemployment rate in Jember. The type of data used in this research was secondary data in the form of 'time series' obtained from Jember Department of Labor and Central Bureau of Statistics in the year of 2002-2013. The research method was a kind of statistical descriptive analysis and multiple linear regression analysis. Moreover, the researcher used partial test (T-test), simultaneous test (F-test), and coefficients determination test (R2) for the hypothesis. Whereas the assumption test was conducted in the use of normality, multicollinearity, heteroscedasticity, and autocorrelation test. From the result of the data analysis, it confirmed that the population positively and significantly affected the unemployment rate in Jember. The variables of inflation, minimum wage, and human development index negatively and significantly affected the unemployment rate in Jember. Whereas the variables of economic growth positively and significantly affected unemployment rate in Jember. Finally, the result of the data analysis highlighted the variables of population, inflation, minimum wage,economic growth, and human development index that simultaneously and significantly affected unemployment rate in Jember.

Keywords: Economic Growth, Human Development Index, Inflation, Minimum Wage, Population

\section{Pendahuluan}

Pertumbuhan ekonomi merupakan salah satu indikator yang amat penting dalam menilai kinerja suatu perekonomian, terutama untuk melakukan analisis tentang hasil pembangunan ekonomi yang telah dilaksanakan suatu Negara atau suatu daerah. Ekonomi dikatakan mengalami pertumbuhan apabila produksi barang dan jasa meningkat dari tahun sebelumnya. Pertumbuhan ekonomi menunjukkan sejauh mana aktivitas perekonomian dapat menghasilkan tambahan pendapatan atau kesejahteraan masyarakat pada periode tertentu. Pertumbuhan ekonomi suatu negara atau suatu wilayah yang terus menunjukkan peningkatan menggambarkan bahwa perekonomian negara atau wilayah tersebut berkembang dengan baik (Amir,2007).

Pembangunan ekonomi adalah sebuah proses multidimensi yang melibatkan perubahan-perubahan besar dalam struktur sosial, sikap masyarakat, dan kelembagaan nasional, seperti halnya percepatan pertumbuhan ekonomi, pengurangan ketidakmerataan dan pemberantasan kemiskinan mutlak (Todaro,1988). Sedangkan pembangunan ekonomi daerah adalah suatu proses dimana pemerintah daerah dan masyarakat mengelola sumber daya yang ada dan membentuk suatu pola kemitraan antara pemerintah daerah dengan sektor swasta untuk menciptakan suatu lapangan kerja baru dan merangsang perkembangan kegiatan ekonomi (pertumbuhan ekonomi) dalam wilayah tersebut. Setiap upaya pembangunan ekonomi daerah mempunyai tujuan utama untuk meningkatkan jumlah dan jenis peluang kerja untuk masyarakat daerah (Arsyad,2010).

Pertumbuhan penduduk yang semakin meningkat dari tahun-

1 Corresponding Author

e-Journal Ekonomi Bisnis dan Akuntansi, 2017, Volume IV (1) : 117-121 
ketahun mengakibatkan ketidakseimbangan antara pertumbuhan lapangan pekerjaan dengan bertambahnya tenaga kerja. Hal itu akan menimbulkan kelebihan penawaran tenaga kerja daripada permintaannya, sehingga memunculkan fenomena pengangguran. Di satu sisi, pengangguran menunjukkan adanya selisih antara permintaan (demand of labour) dan penawaran tenaga kerja (supply of labour) dalam suatu perekonomian. Sedangkan pertambahan penduduk yang semakin pesat dan semakin besar jumlahnya menyebabkan masalah pengangguran menjadi bertambah buruk (Budiarto, 1985).

Berdasarkan Publikasi keadaan tenaga kerja Jawa Timur menunjukkan bahwa jumlah pengangguran di Kabupaten Jember mengalami kenaikan dari tahun ke tahun. Pada tahun 2010 jumlah pengangguran di Kabupaten Jember mencapai 31.472 jiwa hingga pada tahun 2013 mengalami kenaikan sebesar 45.619 jiwa (Publikasi Keadaan Tenaga Kerja Jawa Timur, 2013). Permasalahan pengangguran memang sangat kompleks untuk dibahas dan merupakan isu penting, karena dapat dikaitkan dengan beberapa indikator-indikator. Indikator-indikator ekonomi yang mempengaruhi tingkat pengangguran antara lain pertumbuhan ekonomi negara bersangkutan, tingkat inflasi, serta besaran upah yang berlaku.

Penelitian ini bertujuan antara lain untuk menganalisis: Pengaruh jumlah penduduk, tingkat inflasi, tingkat upah minimum, pertumbuhan ekonomi, indeks pembangunan manusia terhadap tingkat pengangguran di Kabupaten Jember.

\section{Metode}

\section{Jenis Penelitian}

Penelitian ini merupakan penelitian explanatory research dan deskriptif. Explanatory research yaitu metode penelitian yang menjelaskan hubungan antara variabel-variabel bebas dan variabel terikat sedangkan deskriptif yaitu mendeskripsikan sejumlah variabel yang berkenaan dengan masalah dan unit yang diteliti antara fenomena yang diuji (Singarimbun,1995).

\section{Waktu dan Lokasi Penelitian}

Penelitian ini dilakukan di Kabupaten Jember Provinsi Jawa Timur dan dilaksanakan pada bulan Oktober 2015.

\section{Jenis dan Sumber Data}

Data yang digunakan dalam penelitian ini adalah data sekunder yang bersifat kuantitatif yaitu data yang diperoleh dari Badan Pusat Statistik (BPS) Kabupaten Jember, BPS Jawa Timur, DISNAKER Kabupaten Jember dalam bentuk angka-angka dan masih perlu dianalisis kembali, dengan tentang data yang digunakan dari tahun 2002 - 2013 tentang jumlah penduduk, tingkat inflasi, tingkat Upah Minimum Kabupaten (UMK), pertumbuhan ekonomi dan indeks pembangunan manusia. Ruang lingkup data yang digunakan adalah Kabupaten Jember Provinsi Jawa Timur.

\section{Metode Analisis Data}

Alat analisis yang digunakan dalam penelitian ini adalah analisis deskriptif statistik, analisis regresi linier berganda, uji hipotesis, uji normalitas, uji asumsi klasik untuk menganalisis faktor yang mempengaruhi tingkat pengangguran di kabupaten jember.

\section{Analisis Deskriptif Statistik}

Analisis deskriptif statistik adalah menggambarkan tentang ringkasan data-data penelitian seperti mean, standar deviasi, varian, modus, dll. Analisis deskriptif ini dapat digunakan untuk memberikan penjelasan dalam penelitian lanjutan untuk memberikan hasil yang lebih baik terhadap analisis regresi. Analisis deskriptif bersifat penjelasan statistik dengan memberikan gambaran data tentang jumlah data, minimum, maxsimum, mean, dan standar deviasi (Prayitno,2010).

\section{Analisis Regresi Linier Berganda}

Untuk mengetahui jumlah penduduk, tingkat inflasi, tingkat upah minimum, pertumbuhan ekonomi dan indeks pembangunan manusia terhadap tingkat pengangguran di Kabupaten Jember, digunakan analisis linier berganda menurut (Prayitno,2010) :

$$
Y=b_{0}+b_{1} X_{1}+b_{2} X_{2}+b_{3} X_{3}+b_{4} X_{4}+b_{5} X_{5}+e
$$

Keterangan :

\section{$\mathrm{Y}$ : Tingkat pengangguran}

$\mathrm{b}_{0}$ : Besarnya pengaruh tingkat pengangguran pada saat jumlah penduduk, tingkat inflasi, tingkat upah minimum, pertumbuhan ekonomi, indeks pembangunan manusia sama dengan nol

$\mathrm{b}_{1}$ : Besarnya jumlah penduduk terhadap tingkat pengangguran

$\mathrm{b}_{2}$ : Besarnya tingkat inflasi terhadap tingkat pengangguran

$\mathrm{b}_{3}$ : Besarnya tingkat upah minimum terhadap tingkat pengangguran

$\mathrm{b}_{4}$ : Besarnya pertumbuhan ekonomi terhadap tingkat pengangguran

$\mathrm{b}_{5}$ : Besarnya indeks pembangunan manusia terhadap tingkat pengangguran

$\mathrm{X}_{1}$ : Jumlah Penduduk

$\mathrm{X}_{2}$ : Tingkat inflasi

$\mathrm{X}_{3}$ : Tingkat upah minimum

$\mathrm{X}_{4}$ : Pertumbuhan ekonomi

$\mathrm{X}_{5}$ : Indeks pembangunan manusia

e : Variabel Pengganggu

\section{Uji Hipotesis}

1. Uji F

2. $\mathrm{Uji} \mathrm{t}$

3. $\mathrm{Uji} \mathrm{R}^{2}$

\section{Uji Asumsi Klasik}

\section{Uji Normalitas Model}

Mendeteksi normalitas dengan melihat penyebaran data titik pada sumbu diagonal dari grafik (Latan,2013). Dasar pengambilan keputusan antara lain :

a. Jika data menyebar disekitar garis diagonal dan mengikuti arah garis diagonal, maka model regresi rnemenuhi asumsi normalitas;

b. Jika data menyebar jauh dari garis diagonal dan atau tidak mengikuti arah garis diagonal, maka model regresi tidak memenuhi asumsi normalitas.

\section{Uji Multikolinearitas}


Gejala multikolinearitas juga dapat dideteksi dengan melihat besarnya VIF (Variance Inflution Factor). Latan (2013), menyatakan bahwa indikasi multikolinearitas pada umumnya terjadi jika VIF lebih dari 10, maka variabel tersebut mempunyai persoalan multikolinieritas dengan variabel bebas lainnya.

\section{Uji Heteroskedastisitas}

Cara memprediksi ada tidaknya heteroskedastisitas pada suatu model dapat dilihat dari pola gambar scatterplot model tersebut (Latan,2013). Dasar pengambilan keputusan antara lain :

1) Jika ada pola tertentu. seperti titik-titik (point-point) yang ada membentuk suatu pola tertentu yang teratur (bergelombang, melebar kemudian menyempit), maka telah terjadi heteroskedastisitas;

2) Jika tidak ada pola yang jelas serta titik-titik menyebar diatas dan dibawah angka 0 pada sumbu Y, maka tidak terjadi heteroskedastisitas

\section{Uji Autokorelasi}

Untuk menguji adanya autokorelasi dapat dideteksi dengan uji Durbin-Watson test. Pengujian yang dilakukan yaitu dengan melakukan pengujian pada nilai Durbin-Watson (D$W$ ) untuk mendeteksi adanya korelasi dalam setiap model. Apabila nilai Durbin-Watson statistik terletak -2 sampai dengan +2 maka tidak terdapat adanya gejala autokorelasi dengan level of significant yang digunakan dalam penelitian adalah 5\% (Sarwono,2013).

\section{Hasil dan Pembahasan}

\section{Hasil Penelitian}

\section{Analisis Deskriptif Statistik}

\section{Tabel 1. Hasil Analisis Deskriptif Statistik}

\begin{tabular}{lcccc}
\hline \multicolumn{1}{c}{ Keterangan } & $\mathrm{N}$ & Minimum & Maximum & Mean \\
\hline Jumlah penduduk $\left(\mathrm{X}_{1}\right)$ & 12 & 2123968 & 2529967 & $2.23 \mathrm{E} 6$ \\
Inflasi $\left(\mathrm{X}_{2}\right)$ & 12 & 2.43 & 16.84 & 7.3025 \\
Upah minimum $\left(\mathrm{X}_{3}\right)$ & 12 & 315500 & 1091950 & $6.46 \mathrm{E} 5$ \\
Pertumbuhan ekonomi $\left(\mathrm{X}_{4}\right)$ & 12 & 3.94 & 7.21 & 5.6958 \\
Indeks pembangunan $\left(\mathrm{X}_{5}\right)$ & 12 & 58.10 & 66.31 & 63.1750 \\
Tingkat pengangguran $(\mathrm{Y})$ & 12 & 2.71 & 11.43 & 6.0617 \\
\hline
\end{tabular}

Sumber : data diolah, 2015

Berdasarkan tabel 1, berkaitan dengan analisis deskriptif statistik dapat dilihat bahwa dengan jumlah data sebanyak 12 , variabel jumlah penduduk $\left(\mathrm{X}_{1}\right)$ mempunyai rata-rata 2,23E6 atau 2.230.000 orang, dengan nilai minimal 2.123.968 orang dan maksimal 2.529.967 orang. Variabel inflasi $\left(\mathrm{X}_{2}\right)$ mempunyai rata-rata sebesar $7,3 \%$, dengan nilai minimal $2,43 \%$ dan maksimal 16,84\%. Variabel upah minimum $\left(\mathrm{X}_{3}\right)$ mempunyai rata-rata sebesar Rp 646.000 dengan nilai minimal Rp 315.500 dan maksimal Rp. 1.091.950. Variabel pertumbuhan ekonomi $\left(\mathrm{X}_{4}\right)$ mempunyai rata-rata sebesar 5,69\%, dengan nilai minimal 3,94\% dan maksimal 7,21\%. Variabel indeks pembangunan manusia $\left(\mathrm{X}_{5}\right)$ mempunyai ratarata sebesar $63,17 \%$, dengan nilai minimal 58,10\% dan maksimal $66,31 \%$. Variabel tingkat pengangguran (Y) mempunyai rata-rata sebesar $6,06 \%$, dengan nilai minimal $2,71 \%$ dan maksimal $11,43 \%$.

\section{Analisis Regresi Linier Berganda}

Tabel 2. Hasil Analisis Regresi Linier Berganda

\begin{tabular}{|c|c|c|c|c|c|c|c|}
\hline \multirow{2}{*}{$\begin{array}{c}\text { Variabel } \\
\text { Independent }\end{array}$} & \multirow{2}{*}{$\begin{array}{l}\text { Stcondcor cilzed } \\
\text { Coeffic ients } B\end{array}$} & \multirow{2}{*}{$\mathrm{t}$} & \multirow{2}{*}{$t_{\text {tabel }}$} & \multirow{2}{*}{\multicolumn{2}{|c|}{ Sig. }} & \multirow{2}{*}{$a$} & \multirow{2}{*}{ Keterangan } \\
\hline & & & & & & & \\
\hline Constant) & 14,097 & & - & & - & & - \\
\hline $\begin{array}{l}\text { amlah penduduk } \\
\left.\mathrm{X}_{1}\right)\end{array}$ & 0,276 & 2,810 & $>2,446$ & 0,013 & $<$ & 0,05 & Signifikan \\
\hline fflasi $\left(\mathrm{X}_{2}\right)$ & $-0,255$ & $-2,615$ & $>-2,446$ & 0,019 & $<$ & 0,05 & Signifikan \\
\hline Ipah minimum $\left(\mathrm{X}_{3}\right)$ & $-0,452$ & $-4,448$ & $>-2,446$ & 0,000 & $<$ & 0,05 & Signifikan \\
\hline $\begin{array}{l}\text { ertumbuhan } \\
\text { konomi }\left(\mathrm{X}_{4}\right)\end{array}$ & 0,204 & 1,905 & $<2,446$ & 0,135 & $>$ & 0,05 & $\begin{array}{c}\text { Tidak } \\
\text { Signifikan }\end{array}$ \\
\hline $\begin{array}{l}\text { 1deks } \\
\text { embangunan }\left(\mathrm{X}_{5}\right)\end{array}$ & $-0,436$ & $-4,242$ & $>-2,446$ & 0,001 & $<$ & 0,05 & Signifikan \\
\hline \multicolumn{4}{|c|}{ djusted $R$ Square $=0,783$} & \multicolumn{4}{|c|}{$\begin{array}{l}\text { F. Hitung }=6,963 \\
\text { Sig. } F=0,022\end{array}$} \\
\hline
\end{tabular}

Sumber : data diolah, 2015

Berdasarkan koefisien regresi, maka persamaan regresi yang dapat dibentuk adalah;

$\mathrm{Y}=14,097+0,276 \mathrm{X}_{1}-0,255 \mathrm{X}_{2}-0,452 \mathrm{X}_{3}+0,204 \mathrm{X}_{4}-0,436 \mathrm{X}_{5}$

a. Nilai konstanta 14,097 , menunjukkan bahwa jika tidak ada jumlah penduduk, inflasi, upah minimum,pertumbuhan ekonomi dan indeks pembangunan maka nilai tingkat penggangguran sebesar 14,097 persen;

b. Nilai koefisien 0,276 pada jumlah penduduk, menunjukkan bahwa setiap ada tambahan jumlah penduduk sebesar 1 jiwa meningkatkan jumlah tingkat pengangguran sebanyak 0,276 jiwa;

c. Nilai koefisien -0,255 pada inflasi, menunjukkan bahwa setiap ada tambahan inflasi akan menurunkan tingkat pengangguran sebesar 0,255 persen;

d. Nilai koefisien $-0,452$ pada upah minimum, menunjukkan bahwa setiap ada tambahan upah minimum akan menurunkan tingkat pengangguran sebesar 0,452 rupiah;

e. Nilai koefisien 0,204 pada pertumbuhan ekonomi, menunjukkan bahwa setiap ada tambahan pertumbuhan ekonomi akan meningkatkan tingkat pengangguran sebesar 0,204 persen;

f. Nilai koefisien $-0,436$ pada indeks pembangunan, menunjukkan bahwa setiap ada tambahan indeks pembangunan akan menurunkan tingkat pengangguran sebesar 0,436 persen.

\section{Uji Hipotesis}

\section{Uji F}

Berdasarkan hasil analisis regresi linear berganda (dalam hal ini untuk menguji pengaruh secara simultan) diperoleh hasil, yaitu bahwa $F_{\text {hitung }}>F_{\text {tabel }}(6,963>4,36)$ dan signifikasi $(0,022<0,05)$, maka Ho ditolak dan Ha diterima, artinya variabel jumlah penduduk, inflasi, upah minimum, pertumbuhan ekonomi dan indeks pembangunan secara simultan berpengaruh signifikan terhadap tingkat pengangguran di Kabupaten Jember.

\section{Uji t}

Berdasarkan hasil analisis regresi linear berganda (dalam hal ini untuk menguji pengaruh secara parsial) diperoleh hasil Jumlah penduduk, inflasi, upah minimum, indeks 
pembangunan manusia berpengaruh signifikan terhadap tingkat pengangguran di Kabupaten Jember. Sedangkan pertumbuhan ekonomi tidak berpengaruh signifikan terhadap tingkat pengangguran di Kabupaten Jember.

\section{Uji Normalitas}

Tabel 3. Hasil Uji Normalitas

\begin{tabular}{lcccc}
\hline \multirow{2}{*}{ Test of Normality } & \multicolumn{4}{c}{ Kolmogorov-Smirnov } \\
\cline { 2 - 5 } & Sig. & & Cutt off & Keterangan \\
\hline Jumlah penduduk $\left(\mathrm{X}_{1}\right)$ & 0,200 & $>$ & 0,05 & Normal \\
Inflasi $\left(\mathrm{X}_{2}\right)$ & 0,898 & $>$ & 0,05 & Normal \\
Upah minimum $\left(\mathrm{X}_{3}\right)$ & 0,957 & $>$ & 0,05 & Normal \\
Pertumbuhan ekonomi $\left(\mathrm{X}_{4}\right)$ & 0,948 & $>$ & 0,05 & Normal \\
Indeks pembangunan $\left(\mathrm{X}_{5}\right)$ & 0,942 & $>$ & 0,05 & Normal \\
Tingkat penggangguran $(\mathrm{Y})$ & 0,862 & $>$ & 0,05 & Normal \\
\hline
\end{tabular}

Sumber : data diolah, 2015

Berdasarkan tabel 3, dapat diketahui bahwa nilai probabilitas atau signifikansi untuk masing-masing variabel lebih besar dari 0,05 , sehingga dapat dinyatakan bahwa data dalam penelitian ini berdistribusi normal.

\section{Uji Asumsi Klasik}

Pengujian asumsi klasik dilakukan untuk melihat apakah model bersifat BLUE. Hasil analisis pada model regresi linier berganda menunjukkan bahwa model memenuhi asumsi normalitas, tidak terjadi multikolinieritas, tidak ada heteroskedastisitas dan tidak terjadi autokorelasi.

\section{Pembahasan}

Hasil pengujian koefisien dari analisis regresi linear berganda, menunjukkan bahwa jumlah penduduk, inflasi, upah minimum, dan indeks pembangunan manusia berpengaruh signifikan terhadap tingkat pengangguran di Kabupaten Jember. Sedangkan variabel pertumbuhan ekonomi tidak berpengaruh signifikan terhadap tingkat pengangguran di Kabupaten Jember. Variabel jumlah penduduk berpengaruh signifikan terhadap tingkat pengangguran di Kabupaten Jember. Hal ini dikarenakan jumlah penduduk yang ada di Kabupaten Jember dalam setiap tahunnya mengalami peningkatan, peningkatan yang ada dapat disebabkan oleh meningkatnya jumlah penduduk asli Jember ataupun juga penduduk pendatang dari luar Kabupaten Jember. Jumlah penduduk yang besar dari Kabupaten Jember, tentunya akan memberikan sedikit masalah dalam penambahan jumlah pengangguran yang ada, namun dalam hal ini penduduk yang ada di Kabupaten Jember juga dapat melakukan sebuah kegiatan yang berhubungan dengan suatu kewirausahaan yang akan memberikan sumber pendapatan kepada penduduk yang ada di Kabupaten Jember. Hal ini sesuai dengan teori Malthus bahwa pertumbuhan penduduk yang tinggi akan menyebabkan kebutuhan konsumsi lebih banyak daripada kebutuhan untuk berinvestasi sehingga sumber daya yang ada hanya dialokasikan lebih banyak ke pertumbuhan tenaga kerja yang tinggi daripada untuk meningkatkan kapital kepada setiap tenaga kerja sehingga akan menyebabkan penyerapan tenaga kerja yang lambat di sektor-sektor modern dan meningkatkan pengangguran (Pramusinta, 2012)

Variabel tingkat inflasi berpengaruh signifikan terhadap tingkat pengangguran di Kabupaten Jember. Hal ini dikarenakan tingkat inflasi yang terjadi di Kabupaten Jember memang mengalami fluktuatif atau perubahan dalam setiap tahunnya, peningkatan atau penurunan yang ada dapat disebabkan oleh faktor-faktor yang mempengaruhi inflasi di Kabupaten Jember, namun dengan tingkat inflasi yang ada selama ini, tingkat inflasi yang ada mampu memberikan penurunan terhadap jumlah pengangguran yang ada di Kabupaten Jember, inflasi yang ada dan relatif tidak terlalu tinggi akan memberikan kemampuan pada perusahaan serta sektor ekonomi yang ada untuk dapat memaksimalkan modalnya dalam pengembangan usahanya, perusahaan atau sektor yang ada dapat menyerap tenaga kerja di wilayahnya dan memberikan pengurangan terhadap jumlah pengangguran yang ada di Kabupaten Jember. Berdasarkan hasil dari analisis regresi, bahwa setiap ada peningkatan inflasi maka akan menurunkan tingkat pengangguran. Hal ini sesuai dengan teori kurva Phillips bahwa hubungan antara tingkat inflasi dengan tingkat pengangguran didasarkan pada asumsi bahwa inflasi merupakan cerminan dari adanya kenaikan permintaan agregat. Dengan naiknya permintaan agregat, berdasarkan teori permintaan, permintaan akan naik, kemudian harga akan naik pula. Dengan tingginya harga (inflasi) maka untuk memenuhi permintaan tersebut produsen meningkatkan kapasitas produksinya dengan menambah tenaga kerja (tenaga kerja merupakan satu-satunya input yang dapat meningkatkan output). Akibat dari peningkatan permintaan tenaga kerja, maka dengan naiknya harga-harga (inflasi) pengangguran berkurang (Amir, 2007).

Variabel tingkat upah minimum berpengaruh signifikan terhadap tingkat pengangguran di Kabupaten Jember. Hal ini dikarenakan upah minimum yang ada di Kabupaten Jember dalam setiap tahunnya mengalami peningkatan yang relatif sesuai dengan besarnya kebutuhan konsumsi masyarakatnya dan pendapatan usaha dari perusahaan atau sektor ekonomi yang ada di Kabupaten Jember, peningkatan upah minimum yang relatif stabil akan memberikan kemampuan pada perusahaan, sektor ekonomi dan masyarakat untuk mampu dalam meningkatkan aktivitas usaha dan pengembangan usahanya dan ketika usaha yang ada meningkat dan mengembang maka perusahaan atau usaha yang ada di Kabupaten Jember dapat memberikan kontribusi terhadap penyerapan tenaga kerja dan pengurangan terhadap pengangguran yang ada di Kabupaten Jember. Hal ini sesuai dengan penjelasan Mankiw (2007) bahwa jika upah yang ditetapkan pada suatu daerah terlalu rendah, maka akan berakibat pada tingginya jumlah pengangguran yang terjadi pada daerah tersebut.

Variabel pertumbuhan ekonomi tidak berpengaruh signifikan terhadap tingkat pengangguran di Kabupaten Jember. Hal ini dikarenakan pertumbuhan ekonomi yang ada di Kabupaten Jember dalam beberapa tahun terakhir memang mengalami peningkatan yang relatif baik dan hal ini merupakan cerminan dari pertumbuhan sektor yang ada di Kabupaten Jember, namun pertumbuhan ekonomi yang relatif meningkat dalam setiap periode juga belum dapat memberikan mengenai kejelasan dalam pengurangan jumlah pengangguran yang ada di Kabupaten Jember, pertumbuhan ekonomi yang ada memang mengalami peningkatan namun dalam hal ini, jumlah pengangguran atau tingkat pengangguran yang ada tidaklah sebanding dengan tingkat pertumbuhan di Kabupaten Jember. Hal ini dikarenakan pertumbuhan 
ekonomi tidak dibarengi oleh peningkatan kapasitas produksi, sehingga tingkat pengangguran tetap meningkat seiring dengan pertumbuhan ekonomi

Variabel indeks pembangunan manusia berpengaruh signifikan terhadap tingkat pengangguran di Kabupaten Jember. Hal ini dikarenakan indeks pembangunan manusia di Kabupaten Jember dalam setiap periodenya memang mengalami peningkatan yang relatif rendah, indeks yang ada tentunya akan mampu mengurangi jumlah pengangguran yang ada di Kabupaten Jember, ketika indeks pembangunan manusia yang ada di Kabupaten Jember mengalami peningkatan maka dapat diartikan pembangunan otonomi daerah Jember lebih baik daripada tahun sebelumnya, peningkatan indeks yang ada dapat disebabkan oleh faktor pendidikan, kesejahteraan masyarakat yang meningkat dan lain sebagainya, ketika beberapa hal tersebut meningkat dan terus mengalami peningkatan perbaikan maka kualitas manusia atau masyarakat yang ada di Kabupaten Jember juga akan mengalami peningkatan yang relatif baik sehingga peningkatan kualitas dan kemampuan penduduk akan mengurangi jumlah pengangguran. menurut Bappeda Kabupaten Jember (2013), IPM terus meningkat dan menjadi indikator utama sebagai hasil akhir tujuan pembangunan daerah dalam kerangka perwujudan otonomi daerah. Dibidang kesejahteraan sosial, Bappeda mempunyai program penanganan masalah kesejahteraan sosial terhadap PMKS (Penyandang Masalah Kesejahteraan Sosial) dan PSKS (Potensi dan Sumber Kesejahteraan Sosial), program dapat mengurangi pengangguran dan meningkatkan kesejahteraan masyarakat.

\section{Simpulan}

Berdasarkan hasil analisis yang telah dilakukan pada penelitian ini, maka dapat ditarik kesimpulan sebagai berikut, Jumlah penduduk, inflasi, upah minimum, indeks pembangunan manusia berpengaruh signifikan terhadap tingkat pengangguran di Kabupaten Jember. Sedangkan pertumbuhan ekonomi tidak berpengaruh signifikan terhadap tingkat pengangguran di Kabupaten Jember. Variabel yang cenderung berpengaruh terhadap tingkat pengangguran di Kabupaten Jember adalah upah minimum.

\section{Referensi}

Amir, Amri. 2007. Pengaruh Inflasi dan Pertumbuhan Ekonomi terhadap Pengangguran di Indonesia. Jurnal Inflasi dan Pengangguran, Vol.1 (No.1).Hal: 4-9.

Arsyad, Lincolin. 2010. Ekonomi Pembangunan. Edisi kelima.Upp STIE YKPN. Yogyakarta

Badan Pusat Statistik. 2013a. Jawa Timur.

Badan Pusat Statistik. 2013b. Kabupaten Jember .

Budiarto dan Munir, 1985. Teknik Analisa Kependudukan. Rineka Cipta. Jakarta.

Dinas Ketenagakerjaan. 2013. Kabupaten Jember.

Latan, Hengky. 2013. Analisis Multivariat Teknik dan Aplikasi. Alfabeta. Bandung

Mankiw,Gregory, 2007. Principle of Economics. Fitria Liza (Penerjemah) dan Imam Nurmawan (Editor). Makro ekonomi. Penerbit Erlangga. Jakarta

Prayitno, Duwi. 2010. Paham Analisa Data Statistik Dengan SPSS. MediaKom, Yogyakarta.

Pramusinta, Elsa Betha. 2012. Analisis Hubungan Antara Pertumbuhan Penduduk dan Dependency Ratio Dengan Pertumbuhan Ekonomi Kota Semarang Pada Tahun 1986-2008. Skripsi. Fakultas Ekonomi Universitas Diponegoro. Semarang.

Sarwono, Jonathan. 2013. 12 Jurus Ampuh SPSS Untuk Riset Skripsi. PT. Elek Media Komputindo. Jakarta

Singarimbun, M. 1995. Metode Penelitian Survai, Cetakan Kedua. Penerbit Pustaka LP3ES. Jakarta

Todaro, P. Michele. 1988. Ekonomi Pembangunan Jilid 1 edisi 9. Erlangga. Jakarta 